\title{
BMJ Global Health We should not dismiss the possibility of eradicating COVID-19: comparisons with smallpox and polio
}

\author{
Nick Wilson, ${ }^{1}$ Osman D Mansoor, ${ }^{2}$ Matthew J Boyd (D) , ${ }^{3}$ Amanda Kvalsvig, \\ Michael G Baker ${ }^{1}$
}

To cite: Wilson N, Mansoor OD, Boyd MJ, et al. We should not dismiss the possibility of eradicating COVID-19: comparisons with smallpox and polio. BMJ Global Health 2021;6:e006810. doi:10.1136/ bmjgh-2021-006810

Received 3 July 2021 Accepted 13 July 2021
Check for updates

C) Author(s) (or their employer(s)) 2021. Re-use permitted under CC BY-NC. No commercial re-use. See rights and permissions. Published by BMJ.

${ }^{1}$ Public Health, University of Otago Wellington, Wellington, New Zealand

${ }^{2}$ Gisborne, New Zealand ${ }^{3}$ Adapt Research Ltd, Reefton, New Zealand

Correspondence to Professor Nick Wilson; nick.wilson@otago.ac.nz

\section{INTRODUCTION}

Elimination and eradication of disease are among the ultimate goals of public health ${ }^{1}$ (for definitions see box 1). Vaccination has globally eradicated smallpox, rinderpest (a cattle disease that caused famines ${ }^{2}$ ) and two of the three serotypes of poliovirus. ${ }^{3}$ Three other vaccine-preventable diseases are eradicable globally with current technology, ${ }^{4}$ with measles the leading contender and with MMR vaccination potentially eradicating mumps and rubella at the same time. Some other diseases are close to being eradicated but without use of vaccines such as with the Guinea Worm Eradication Programme. ${ }^{5}$ Similarly, China has recently eliminated malaria with a range of non-vaccination tools, to become the 40th country to be certified malaria-free. ${ }^{6}$

Is COVID-19 also potentially eradicable? Or is it inevitably endemic having established itself across the world? Commentators have focused on the challenges of reaching population (herd) immunity, ${ }^{7}$ yet population immunity is not essential and was not achieved for smallpox, which was eradicated through ring vaccination.

As proof of concept for COVID-19 eradication, several countries and jurisdictions have achieved elimination without vaccination, using new and established public health and social measures (PHSMs) (eg, border control, physical distancing, mask wearing, testing and contact tracing supported by genome sequencing). ${ }^{8}$ Successful jurisdictions have included those with vast land borders such as China, high population densities such as Hong Kong, ${ }^{9}$ but also island nations such as Iceland and New Zealand, although with occasional outbreaks from border control failures that have been brought under control. ${ }^{10}$
Summary box

With the success of public health and social measures (PHSMs) at eliminating COVID-19 in several jurisdictions, combined with the arrival of safe and highly effective vaccines, the question is raised: is global eradication of COVID-19 feasible?

- Our scoring for eradicability suggests that COVID-19 eradication might be slightly more feasible than for polio (although only two of three serotypes eradicated to date), but much less so than smallpox.

- The main challenges are probably around achieving high vaccination coverage and the potential need to update vaccine designs. Yet an advantage for COVID-19 eradication, over that for smallpox and polio, is that PHSMs can complement vaccination. There is also very high global interest in COVID-19 control due to the massive scale of the health, social and economic burden.

- There is a need for a more formal expert review of the feasibility and desirability of attempting COVID-19 eradication by the WHO or coalitions of national health agencies.

Box 1 Definitions of key disease control terms from the Dahlem Workshop ${ }^{19}$

Control: The reduction of disease incidence, prevalence, morbidity or mortality to a locally acceptable level as a result of deliberate efforts; continued intervention measures are required to maintain the reduction. Example: diarrhoeal diseases.

- Elimination of disease: Reduction to zero of the incidence of a specified disease in a defined geographical area as a result of deliberate efforts; continued intervention measures are required. Example: neonatal tetanus.

- Elimination of infections: Reduction to zero of the incidence of infection caused by a specific agent in a defined geographical area as a result of deliberate efforts; continued measures to prevent re-establishment of transmission are required. Example: measles, poliomyelitis.

- Eradication: Permanent reduction to zero of the worldwide incidence of infection caused by a specific agent as a result of deliberate efforts; intervention measures are no longer needed. Example: smallpox.

- Extinction: The specific infectious agent no longer exists in nature or in the laboratory. Example: none. 
Table 1 Factors favouring the eradicability of vaccine-preventable diseases with comparisons between smallpox, polio and COVID-19 (graded for the relative strength of favourability in supporting eradication*)

\begin{tabular}{llll}
\hline Factors favouring eradicability & Smallpox (eradicated) & Polio (2/3 wild serotypes eradicated) & CoVID-19
\end{tabular}

Technical factors favouring eradicability of vaccine-preventable diseases (from Hinman $1999^{4}$ )

A highly effective and safe vaccine (preferably cheap and quite stable)
$+++$

Combined with ring vaccination of contacts this proved to be a 'great success' in smallpox eradication ${ }^{20}$
Subop high enteric infection burdens exist; major problems with vaccine-derived poliovirus spread ${ }^{2}$

Lifelong immunity after natural infection or
immunisation

$+++$

Immunity probably persists for decades $^{23}$
$++$

See row above, although immunity probably life-long after natural infection

Uncertainty around length of protection, some adverse effects concerns with some vaccines; and cannot be used for contact management. Nevertheless, mRNA vaccines are likely to be further improved and there is potential with intranasal spray vaccines ${ }^{22}$

Not known but data suggest robust immune response to COVID-19 vaccines in general, and especially mRNA vaccines

$+++$

A short period of communicability (no long- +++

$+++$

Zero score

$\begin{array}{lll}\begin{array}{l}\text { A highly characteristic clinical syndrome } \\ \text { (preferably with no or few unapparent }\end{array} & +++ & \text { Zero score } \\ \text { infections) } & \text { Typically very distinctive skin lesions } & \begin{array}{l}\text { Only around } 24 \% \text { of those infected } \\ \text { develop clinical signs which are typically } \\ \text { mild and non-specific }{ }^{21}\end{array}\end{array}$

An easy and reliable means of diagnosis

$+++$

See row above

Typically needs a laboratory test for diagnosis; acute flaccid paralysis occurs in 1 per 200 to 1 per 1000 cases

$\begin{array}{lll}\begin{array}{l}\text { The absence of a non-human (or } \\ \text { environmental) reservoir }\end{array} & \begin{array}{l}+++ \\ \text { No such reservoirs }\end{array} & \begin{array}{l}+++ \\ \text { No such reservoirs }\end{array} \\ \begin{array}{ll}\text { A genetically stable causative agent, and } \\ \text { seasonality of occurrence }\end{array} & \begin{array}{l}+++ \\ \text { Stable and some evidence for } \\ \text { seasonality }^{25}\end{array} & \begin{array}{l}++ \\ \text { Stable and seasonal in temperate zones } \\ \text { but not the tropics }\end{array}\end{array}$

While around $30 \%$ of infections are asymptomatic, ${ }^{24}$ illness is typically more severe and some symptoms are more specific than for polio, for example, anosmia

Needs a laboratory test for diagnosis

$++$

There is some risk that other reservoirs might become established-see main text

New variants may be a problem with some vaccines ${ }^{27}$; seasonality still unclear

\section{Additional technical factors favouring eradicability (author additions)}

Relatively low transmissibility (basic reproduction number, $\mathrm{R} 0$ ) resulting in low population immunity threshold (PIT) and greater ease of achieving and sustaining sufficient vaccination coverage

$++$ $\mathrm{RO}=4.5, \mathrm{PIT}=78 \%\left(\right.$ source $\left.^{28}\right)$
$+$ $\mathrm{RO}=6.0, \mathrm{PIT}=84 \%\left(\right.$ source $\left.^{28}\right)$

Initially $\mathrm{R0}=2.5, \mathrm{PIT}=60 \%\left(\right.$ source $\left.^{28}\right)$, but as of mid-2021 with new variants circulating these figures are probably now much higher in most settings

Vaccination can be supported by PHSMs, for example, border controls, physical distancing, hygiene, improved ventilation, mask use, contact tracing (with quarantine and isolation) and community engagement

Environmental surveillance can contribute

$+++$

Contact tracing with ring vaccination of these contacts proved to be a 'great success' with eradication $^{20}$
$+$ Sanitation improvements can potentially play a role but are far more expensive than vaccination. Community available in various Asia-Pacific involvement assists with national countries ${ }^{10}$ immunisation days ${ }^{29}$

Wastewater testing is used and can focus enhanced vaccination efforts ${ }^{30}$

Not included in the scoring as it is not relevant due to the highly characteristic clinical syndromesee above.
Important with PHSMs achieving

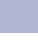

$++$

Wastewater testing ${ }^{31}$ is proving valuable in elimination settings (allowing enhanced additional surveillance)

Additional socio-political and economic factors favouring eradicability (author additions and building on Dowdle $1998^{1}$ and Hinman $1999^{4}$ )

Governments can manage disease control messaging (eg, promote vaccination and/ or PHSMs)

$+++$

Largely true for the eradication period 1959 to 1979
Largely true for much of the period 1988 Media, and especially social media, to 2021 , although eradication is ongoing are now less favourable to the goals for one serotype in two countries

\section{$+$}

Public and political concern about the health ++

burden from the disease (including on health At the time the programme started inequalities) of government health messaging. Actual governments are involved in 'antiscience aggression'13 in 1959: probably moderate concern 1988: probably some concern in the in the 59 countries with endemic 125 countries with endemic disease; disease; total of $\geq 20$ million cases/ total of 350000 cases/year ${ }^{32}$
$+++$

Very high in nearly all countries; an estimated 7.1 million deaths globally from January 2020 to 3 May $2021^{33}$

Continued 
Table 1 Continued

\begin{tabular}{|c|c|c|c|}
\hline Factors favouring eradicability & Smallpox (eradicated) & Polio (2/3 wild serotypes eradicated) & CovID-19 \\
\hline $\begin{array}{l}\text { Public and political concern about the social } \\
\text { and economic impacts of the disease (from } \\
\text { illness and control measures required) }\end{array}$ & $\begin{array}{l}+ \\
\text { As per the row directly above; but } \\
\text { also around the ongoing cost of } \\
\text { vaccination in both endemic and } \\
\text { non-endemic countries }\end{array}$ & ${ }^{+}$As per the row directly above & $\begin{array}{l}+++ \\
\text { Very high in } 2021 \text { in all countries. } \\
\text { In the USA alone trillions of dollars } \\
\text { have had to be spent because of } \\
\text { the pandemic }{ }^{34}\end{array}$ \\
\hline $\begin{array}{l}\text { Public acceptability of control measures } \\
\text { needed to achieve eradication (vaccination } \\
\text { and PHSMs) }\end{array}$ & $\begin{array}{l}+++ \\
\text { High acceptability given the very } \\
\text { targeted interventions such as ring } \\
\text { vaccination }\end{array}$ & $\begin{array}{l}++ \\
\text { Generally high acceptability of the } \\
\text { vaccine, although occasional problems } \\
\text { in some settings }\end{array}$ & $\begin{array}{l}++ \\
\text { Problems with vaccine hesitancy } \\
\text { in some countries as of mid-2021 } \\
\text { and resistance to some PHSMs, for } \\
\text { example, mask wearing }\end{array}$ \\
\hline $\begin{array}{l}\text { Relatively low up-front cost of achieving } \\
\text { eradication }\end{array}$ & $\begin{array}{l}+++ \\
\text { Relatively low cost at US } \$ 298 \text { million } \\
\text { in } 1970 \text { s dollars }{ }^{35}\end{array}$ & $\begin{array}{l}++ \\
\text { Polio eradication efforts cost } \\
\$ 16.5 \text { billion (US, nominal) for 1988- } \\
2018^{36}\end{array}$ & $\begin{array}{l}+ \\
\text { Largely unknown, but the costs are } \\
\text { probably vast (eg, } \$ 66 \text { billion to just } \\
\text { vaccinate populations in low-income } \\
\text { countries) })^{37} \text { Major upgrading health } \\
\text { systems in low-income countries } \\
\text { might also be needed }\end{array}$ \\
\hline $\begin{array}{l}\text { Relatively favourable benefit to cost ratio of } \\
\text { attempting and then achieving eradication }\end{array}$ & $\begin{array}{l}+++ \\
\text { Very large benefit to cost ratios, } \\
\text { 'probably the greatest global public } \\
\text { investment in human history'35 }\end{array}$ & $\begin{array}{l}++ \\
\text { Estimated incremental net benefits } \\
\text { of eradication are very large at } \\
\text { US } \$ 28 \text { billion in } 2019^{36} \text { (but there is still } \\
\text { uncertainty around ultimate success - } \\
\text { that is, the remaining serotype) }\end{array}$ & $\begin{array}{l}+ \\
\text { Unknown, but the benefit to cost } \\
\text { ratio might still be very favourable } \\
\text { given the possible high cost on } \\
\text { health systems of endemic disease } \\
\text { and if repeat vaccinations are } \\
\text { required (as seen with influenza } \\
\text { vaccination) }^{38}\end{array}$ \\
\hline $\begin{array}{l}\text { Level of global cooperation to achieve the } \\
\text { collective goal of eradication }\end{array}$ & $\begin{array}{l}++ \\
\text { Initially the campaign 'suffered from } \\
\text { a lack of funds, personnel, and } \\
\text { commitment from countries, and a } \\
\text { shortage of vaccine donations'. }{ }^{9} \text { ' } \\
\text { But cooperation subsequently } \\
\text { improved }\end{array}$ & $\begin{array}{l}+ \\
\text { There have been funding shortfalls }{ }^{29} \\
\text { and in } 2021 \text { there was a high-income } \\
\text { country (the UK) which cut funding } \\
\text { support by } 95 \%{ }^{40}\end{array}$ & $\begin{array}{l}+ \\
\text { There have been vaccine shortfalls } \\
\text { with the COVAX programme: } \\
\text { 'about } 200 \text { million doses behind } \\
\text { where we want to be'. }{ }^{41} \text { There are } \\
\text { also concerns about 'new vaccine } \\
\text { nationalism' and government- } \\
\text { mediated 'antiscience aggression,13 }\end{array}$ \\
\hline $\begin{array}{l}\text { Totals and means (with the highest score } \\
\text { being }+++ \text { for each of the applicable } \\
\text { categories) }\end{array}$ & Total $=43 / 48 ;$ mean $=2.7$ & Total $=26 / 51 ;$ mean $=1.5$ & Total $=28 / 51 ;$ mean $=1.6$ \\
\hline
\end{tabular}

*Our preliminary assessment for the likely relative strength of favourability for each factor in terms of supporting the eradicability of each pathogen using the following scale: +++ high; ++ medium; + low, and 'zero score'.

PHSMs, public health and social measures.

\section{COMPARISONS WITH SMALLPOX AND POLIO FOR ERADICABILITY}

To make comparisons between smallpox, polio, and COVID-19, we consider established technical factors that favour the eradicability of vaccine-preventable diseases, published in $1999^{4}$ (table 1 ). To this list we added additional technical, socio-political, and economic factors that are likely to favour achieving eradication. On our scoring for eradicability using a three-point relative scale across 17 variables, the mean (total) scores were smallpox at 2.7 (43/48), then COVID-19 at $1.6(28 / 51)$, and finally polio at $1.5(26 / 51)$ (table 1$)$. While our analysis is a preliminary effort with various subjective components, it does seem to put COVID-19 eradicability into the realms of being possible, especially in terms of technical feasibility.

The technical challenges of COVID-19 eradicability (relative to smallpox and polio) include poor vaccine acceptance, and the emergence of more variants that may be more transmissible or have greater immuno-evasion, potentially allowing vaccine escape so they can outrun global vaccination programmes. ${ }^{11}$ Nevertheless, there are of course limits to viral evolution, so we can expect the virus to eventually reach peak fitness ${ }^{12}$ and new vaccines can be formulated.
Other challenges would be the high upfront costs (for vaccination and upgrading health systems), and achieving the necessary international cooperation in the face of 'vaccine nationalism' and government-mediated 'antiscience aggression'. ${ }^{13}$

Another concern is the risk of the persistence of the pandemic virus in non-human animal reservoirs. However, wild animal infections with SARS-CoV-2 appear to be fairly rare to date, ${ }^{14}$ and when companion animals become infected they do not appear to re-infect humans. ${ }^{15}$ Infections among farmed animals could potentially be controlled by quarantining and culling. Furthermore, COVID-19 vaccines for domestic animals are being developed (as they were for the eradication of rinderpest ${ }^{2}$ ) and oral vaccine in bait has effected successful regional elimination of rabies in wild foxes. ${ }^{16}$ Furthermore, the problem of Guinea worm infection in domestic dogs has not stopped the global eradication efforts for that disease, ${ }^{5}$ since various non-vaccination control measures can be successfully used in dogs.

On the other hand, the massive scale of the health, social and economic burden from COVID-19 in most of the world means that there is unprecedented global interest in disease control and massive investment in vaccination against the pandemic. There is also the advantage for COVID-19 
eradication over these other diseases in that PHSMs can be highly effective and can complement vaccination. The upgrading of health systems to facilitate COVID-19 eradication could also have large co-benefits for controlling other diseases (and indeed eradicating measles as well). Collectively these factors might mean that an 'expected value' analysis could ultimately estimate that the benefits outweigh the costs, even if eradication takes many years and has a significant risk of failure.

\section{POTENTIAL NEXT STEPS}

The preliminary assessment we have performed indicates the value of further work on the potential for the eradication of COVID-19. This work would ideally be done by the WHO, but failing that it could be done by coalitions of national-level agencies working collaboratively. Any expert review needs to consider two main questions: (1) Could sustained COVID-19 eradication be technically feasible with currently available technologies? (2) Should eradication be attempted based on its desirability in terms of benefits versus costs (which provides the context of opportunity cost) and the risk of failure? It should also take a more sophisticated approach than we have by giving the different categories weights and also by making comparisons with measles, where elimination has been achieved at times for large regions (eg, the Americas ${ }^{17}$ ) and which is potentially eradicable. ${ }^{5}$ Modelling work that integrates both the health and economic aspects of COVID-19 control (as per recent work in Australia ${ }^{18}$ ) should also inform the decision-making processes.

\section{CONCLUSIONS}

In this very preliminary analysis, COVID-19 eradication seems slightly more feasible than for polio, but much less so than for smallpox. There is a need for a more formal expert review of the feasibility and desirability of attempting COVID-19 eradication by the WHO or other agencies.

Twitter Matthew J Boyd @matt_adapt

Contributors NW, ODM and MB are New Zealand based public health physicians/ epidemiologists. AK is an epidemiologist. $\mathrm{MJ}$ is a philosopher and catastrophic risks researcher. Content of this analysis was drawn from the experience of smallpox and polio eradication and on the epidemiology and control of COVID-19 to date. NW conceived the paper and wrote the initial draft. MJB and MB contributed to methodological issues. All authors contributed to revisions of the text. All authors approved the final version of the manuscript.

Funding The authors have not declared a specific grant for this research from any funding agency in the public, commercial or not-for-profit sectors.

Competing interests ODM reports membership in three boards/committees: the Specialist Council of the New Zealand Medical Association; the GAVI Independent Review Committee; and the Immunisation Advisory Committee (in New Zealand).

Patient consent for publication Not required.

Provenance and peer review Not commissioned; internally peer reviewed.

Data availability statement All data relevant to the study are included in the article.

Open access This is an open access article distributed in accordance with the Creative Commons Attribution Non Commercial (CC BY-NC 4.0) license, which permits others to distribute, remix, adapt, build upon this work non-commercially, and license their derivative works on different terms, provided the original work is properly cited, appropriate credit is given, any changes made indicated, and the use is non-commercial. See: http://creativecommons.org/licenses/by-nc/4.0/.

\section{ORCID iD}

Matthew J Boyd http://orcid.org/0000-0002-1387-5047

\section{REFERENCES}

1 Dowdle WR. The principles of disease elimination and eradication. Bull World Health Organ 1998;76 Suppl 2:22-5.

2 Roeder P, Mariner J, Kock R. Rinderpest: the veterinary perspective on eradication. Philos Trans $R$ Soc Lond B Biol Sci 2013;368:20120139.

3 Polio Global Eradication Initiative. Two out of three wild poliovirus strains eradicated. polio global eradication initiative, 2019. Available: https://web.archive.org/web/20191107080405/http:// polioeradication.org/news-post/two-out-of-three-wild-poliovirusstrains-eradicated/

4 Hinman A. Eradication of vaccine-preventable diseases. Annu Rev Public Health 1999;20:211-29.

5 WER. Summary of the 31 st meeting of the International Task Force for Disease Eradication, 20-21 October 2020. Wkly Epidemiol Rec 2021:1-10.

6 Normile D. It's official: China has eliminated malaria. Science, 2021: 29. https://www.sciencemag.org/news/2021/06/it-s-officialchina-has-eliminated-malaria

7 Aschwanden C. Five reasons why COVID herd immunity is probably impossible. Nature 2021:591:520-2.

8 Geoghegan JL, Douglas J, Ren X, et al. Use of genomics to track coronavirus disease outbreaks, New Zealand. Emerg Infect Dis 2021;27:1317-22.

9 Gu H, Xie R, Adam DC, et al. SARS-CoV-2 under an elimination strategy in Hong Kong. medRxiv 2021;23. doi:10.1101/2021.06.19.2 1259169. [Epub ahead of print: 23 Jun 2021]

10 Baker MG, Wilson N, Blakely T. Elimination could be the optimal response strategy for covid-19 and other emerging pandemic diseases. BMJ 2020;371:m4907.

11 Krause PR, Fleming TR, Longini IM, et al. SARS-CoV-2 variants and vaccines. N Engl J Med 2021;385:179-86.

12 Burioni R, Topol EJ. Has SARS-CoV-2 reached peak fitness? Nat Med 2021. doi:10.1038/s41591-021-01421-7. [Epub ahead of print: 21 Jun 2021].

13 Hotez PJ, Narayan KMV. Restoring vaccine diplomacy. JAMA 2021;325:2337-8.

14 Mallapaty S. The search for animals harbouring coronavirus - and why it matters. Nature 2021;591:26-8.

15 EurekAlert! AAAS. Study suggests it is common for PET dogs and cats to catch COVID-19 from their owners. European Society of Clinical Microbiology and Infectious Diseases (news release), 2021. Available: https://www.eurekalert.org/pub_releases/2021-06/esocssi062921.php

16 Brochier B, Pastoret PP. Rabies eradication in Belgium by fox vaccination using vaccinia-rabies recombinant virus. Onderstepoort $J$ Vet Res 1993:60:469-75.

17 Pan American Health Organization. Measles elimination in the Americas. Pan American Health Organization (PAHO). Available: https://www3.paho.org/hq/index.php?option=com content\&view= article\&id=12526: measles-elimination-in-the-americas\&ltemid= 40721\&lang=en [Accessed 9 Jun 2021].

18 Blakely T, Thompson J, Bablani L. Assessment of a range of simulated COVID-19 policy responses for social restrictions and lockdowns associated with health-adjusted life years and costs in Victoria, Australia. JAMA Health Forum;In press.

19 Dowdle WR. The principles of disease elimination and eradication. MMWR 1998:48:23-7.

20 Centers for Disease Control and Prevention. Smallpox: ring vaccination (page last reviewed: 2 December, 2019). Centers for Disease Control and Prevention. Available: https://www.cdc.gov/ smallpox/bioterrorism-response-planning/public-health/ringvaccination.html

21 World Health Organization. Poliomyelitis (updated 14 September 2020). World Health Organization. Available: https://www.who.int/ biologicals/areas/vaccines/poliomyelitis/en/

22 Hassan AO, Kafai NM, Dmitriev IP, et al. A single-dose intranasal Chad vaccine protects upper and lower respiratory tracts against SARS-CoV-2. Cell 2020;183:e13:169-84.

23 Taub DD, Ershler WB, Janowski M, et al. Immunity from smallpox vaccine persists for decades: a longitudinal study. Am J Med 2008;121:1058-64. 
24 Centers for Disease Control and Prevention. COVID-19 pandemic planning scenarios, 2021. Available: https://www.cdc.gov/ coronavirus/2019-ncov/hcp/planning-scenarios.html

25 Nishiura H, Kashiwagi T. Smallpox and season: reanalysis of historical data. Interdiscip Perspect Infect Dis 2009;2009: $1-10$.

26 Centers for Disease Control and Prevention. Poliomyelitis. In: Centers for Disease Control and Prevention, epidemiology and prevention of vaccine-preventable diseases. 13th Edn, 2015. https:// www.cdc.gov/vaccines/pubs/pinkbook/downloads/polio.pdf

27 Kupferschmidt K. New mutations raise specter of 'immune escape'. Science 2021;371:329-30.

28 Omer SB, Yildirim I, Forman HP. Herd immunity and implications for SARS-CoV-2 control. JAMA 2020;324:2095-6.

29 Lahariya C. Global eradication of polio: the case for "finishing the job". Bull World Health Organ 2007;85:487-92.

30 Duintjer Tebbens RJ, Zimmermann M, Pallansch MA, et al. Insights from a systematic search for information on designs, costs, and effectiveness of poliovirus environmental surveillance systems. Food Environ Virol 2017;9:361-82.

31 Lundy L, Fatta-Kassinos D, Slobodnik J, et al. Making waves: collaboration in the time of SARS-CoV-2 - rapid development of an international co-operation and wastewater surveillance database to support public health decision-making. Water Res 2021;199:117167.

32 Keegan R, Dabbagh A, Strebel PM, et al. Comparing measles with previous eradication programs: enabling and constraining factors. $J$ Infect Dis 2011;204 Suppl 1:S54-61.
33 Institute for Health Metrics and Evaluation. Estimation of total mortality due to COVID-19, 2021. Available: www.healthdata.org/ special-analysis/estimation-excess-mortality-due-covid-19-andscalars-reported-covid-19-deaths

34 Congressional Budget Office. An update to the economic outlook: 2020 to 2030. United States Congressional Budget Office, 2020. Available: https://www.cbo.gov/publication/56542

35 Barrett S. Economic considerations for the eradication endgame. Philos Trans R Soc Lond B Biol Sci 2013;368:20120149.

36 Thompson KM, Kalkowska DA. An updated economic analysis of the global polio eradication initiative. Risk Anal 2021;41:393-406.

37 Boseley S. Covid: more than 200 leaders urge $\mathrm{G} 7$ to help vaccinate world's poorest. Guardian, 2021. Available: https://www.theguardian. com/world/2021/jun/06/covid-global-leaders-urge-g7-to-helpvaccinate-worlds-poorest

38 Putri WCWS, Muscatello DJ, Stockwell MS, et al. Economic burden of seasonal influenza in the United States. Vaccine 2018;36:3960-6.

39 Centers for Disease Control and Prevention. Smallpox: history of smallpox (page last reviewed: 20 February, 2021). Centers for Disease Control and Prevention. Available: https://www.cdc.gov/ smallpox/history/history.html

40 Worley W. Exclusive: UK cuts polio funding by 95\%. Devex, 2021 Available: https://www.devex.com/news/exclusive-uk-cuts-poliofunding-by-95-99774

41 France24. WHO warns of June-July Covax doses shortfall, 2021. Available: https://www.france24.com/en/live-news/20210604-whowarns-of-june-july-covax-doses-shortfall 